\title{
Revenge Buying
}

\author{
S. Lakshmi \\ Hindustan Institute of Technology and Science
}

\section{ABSTRACT}

This is the first experience for all us, have been restricted and confined to the four walls of the houses. All people adopt themselves to live according the pandemic situation, the person's outlook towards life. This has a direct impact on the consumer behaviour towards shopping. Retail stores in many malls are yet to open. People are all eagerly waiting to buy leather bags, luxury clothes, accessories and shoes etc but buying of groceries products, mobile phone cannot be termed as revenge buying. According to a report, during lockdown customers go for goods like blazers, precious jewelry as revenge buying. But this revenge buying can't be sustainable in the market because in COVID 19 more than 200 thousand people have lost their jobs. Only consumers having net worth and excess cash in their hand who have missed shopping in their favorite outlets go for revenge buying.

\section{KEY WORDS: COVID 19, REVENGE, BUYING BEHAVIOUR, RETAILERS, LOCKDOWN.}

\section{INTRODUCTION}

Person trip is not complete if one does not go for shopping. Luxury goods manufacturers sold up to million $\$$ in single day sales when the county opened up after a partial relaxation to the lockdown. Business people can get back the lost revenues through this revenge buying strategy. After this lock down people aggressively shops for products they most liked. After this COVID - 19 hunger people go for bulk purchase or aggressively indulging in shopping of whatever they want especially of food products, textiles and cosmetics and the first response was to throng to the luxury stores. Consumer behaviour is undergo a major changes when the economy finally comes out of a shutdown as the country remains under a 6 months lockdown due to coronavirus pandemic.

\section{ARTICLE INFORMATION}

Received 25th Oct 2020 Accepted after revision 17th Dec 2020 Print ISSN: 0974-6455 Online ISSN: 2321-4007 CODEN: BBRCBA

Thomson Reuters ISI Web of Science Clarivate Analytics USA and Crossref Indexed Journal

\section{Clarivate
Analytics}

NAAS Journal Score 2020 (4.31)

A Society of Science and Nature Publication,

Bhopal India 2020. All rights reserved.

Online Contents Available at: http//www.bbrc.in/

Doi: $h t t p: / / d x$.doi.org/10.21786/bbrc/13.15/35
Once the lock down opens up, the consumers will be going for revenge buying, discount seeking and bargain hunting. Consumer behaviour may take a U- turn after the lockdown gets over. Youngsters go for excessive shopping after a long time due to heavy restrictions. There may also a probability for $\mathrm{U}$-turn in the consumer behaviour after the lockdown, the reason is people don't want to spend much amount on luxury items as they think that of a wasteful expenditure because they focus on saving but in other countries like china, US are prone to luxury purchasing.

Literature Review: A brief study of research work on the subject has been presented. Celik, A. and Celylan, M. (2010) states the effects of socio economic factors on the consumption of accessories, leather bags, cosmetics, shoes. People experience different perception after lifting the lock down which should affect their consumer behaviour. Questionnaire are sent through google forms with 111 respondents and collected data are evaluated using One way Anova and Independent sample t- test. The results of the evaluations showed that there are no significant difference between the two variable (revenue Redeemption with age group and gender with level of purchase). 


\section{RESEARCH METHODOLOGY}

\section{Objectives of the Study}

1 . To study about the revenge buying of consumers

2. To analyse the redemption of revenues by the retailers

3. To evaluate the Reciprocal changes in consumer behaviour

Many research studies have been exploring new thoughts and advocating new philosophy of marketing programs. One such new philosophy that gained impetus in the recent past is pertaining to post covid buying behaviour of consumers. People are really tired of sitting at home locked in and they really want to go out and buy. Revenge buying is expected to be dominated between the age group of 15 to 30 because they are eagerly waiting to eat out, to buy cosmetics, accessories and to visit beauty parlors and spa. Group of people will be happy to rush out to buy things that they had not been able to buy out for the last two months. Structured questionnaire has been used to collect the data. Study was based on the primary and secondary data. Convenience sampling was used to collect the opinion of the respondents. 111 is taken as taken as the sample size for further analysis. One way Anova and Independent sample t-test has been used for this study.

Data Analysis and Interpretation: Statistical tools like t- test, Anova are used to analyse the data collected through questionnaire. Data's were collected from the people residing in Chennai city.

\section{Independent Sample T-test:}

HO: The means of the two groups are not significantly different

H1: The means of the two groups are significantly different.

Inference: Here the mean value of level of purchase of female is 1.68 and that of male is 1.40 the difference between the two is 0.28 which is insignificant. Based on the result generated by SPSS, the significant value is 0.068 and it is greater than 0.05 . So accept null hypothesis. Hence there is no significant difference between the two means i.e. there is no significant difference between the gender and the level of purchase made by them.

\begin{tabular}{|c|c|c|c|c|c|}
\hline & \multicolumn{5}{|c|}{ Group Statistics } \\
\hline & Gender & $\mathrm{N}$ & Mean & Std. Deviation & Std. Error Mean \\
\hline \multirow[t]{2}{*}{ Level of purchase } & Male & 55 & 1.40 & .710 & .096 \\
\hline & Female & 56 & 1.68 & .876 & .117 \\
\hline
\end{tabular}

Table 1.2

\begin{tabular}{|c|c|c|c|c|c|c|c|c|c|c|}
\hline \multicolumn{11}{|c|}{ Independent Samples Test } \\
\hline & & \multicolumn{2}{|c|}{$\begin{array}{c}\text { Levene's Test } \\
\text { for Equality of } \\
\text { Variances }\end{array}$} & \multicolumn{7}{|c|}{ t-test for Equality of Means } \\
\hline & & \multirow[b]{2}{*}{$\mathrm{F}$} & \multirow[b]{2}{*}{ Sig. } & \multirow[b]{2}{*}{$\mathrm{T}$} & \multirow[b]{2}{*}{ df } & \multirow{2}{*}{$\begin{array}{l}\text { Sig. (2- } \\
\text { tailed) }\end{array}$} & \multirow{2}{*}{$\begin{array}{c}\text { Mean } \\
\text { Difference }\end{array}$} & \multirow{2}{*}{$\begin{array}{l}\text { Std. Error } \\
\text { Difference }\end{array}$} & \multicolumn{2}{|c|}{$\begin{array}{l}95 \% \text { Confidence } \\
\text { Interval of the } \\
\text { Difference }\end{array}$} \\
\hline & & & & & & & & & Lower & Upper \\
\hline \multirow[t]{2}{*}{$\begin{array}{l}\text { Level of } \\
\text { purchase }\end{array}$} & $\begin{array}{c}\text { Equal } \\
\text { variances } \\
\text { assumed }\end{array}$ & 9.589 & 0.002 & -1.839 & 109 & 0.069 & -0.279 & 0.151 & -0.579 & 0.022 \\
\hline & $\begin{array}{c}\text { Equal } \\
\text { variances not } \\
\text { assumed }\end{array}$ & & & -1.842 & 105.212 & 0.068 & -0.279 & 0.151 & -0.578 & 0.021 \\
\hline
\end{tabular}

Table 1.3

\begin{tabular}{|l|c|c|c|c|c|}
\hline \multirow{2}{*}{} & \multicolumn{5}{|c|}{ ANOVA } \\
& \multicolumn{5}{|c|}{ Revenue redemption } \\
\cline { 2 - 6 } & Sum of Squares & Df & Mean Square & F & Sig. \\
\hline \multirow{2}{*}{$\begin{array}{l}\text { Between Groups } \\
\text { Within Groups }\end{array}$} & .086 & 3 & .029 & .108 & .955 \\
Total & 28.239 & 107 & .264 & & \\
& 28.324 & 110 & & & \\
\hline
\end{tabular}




\section{One Way Anova}

H0; There is no significant difference between the Age group and Redeemption.

H1: There is significant relationship between the Age group and Revenue Redeemption

\section{Table 1.4}

\begin{tabular}{|c|c|c|}
\hline \multicolumn{3}{|c|}{ Revenue Redeemption } \\
\hline \multicolumn{3}{|c|}{ Duncan $^{\mathrm{a}, \mathrm{b}}$} \\
\hline \multirow[t]{2}{*}{ Age group } & $\mathrm{N}$ & Subset for alpha $=0.05$ \\
\hline & & 1 \\
\hline $15-25$ & 22 & 2.64 \\
\hline $36-45$ & 26 & 2.65 \\
\hline 46 and above & 6 & 2.67 \\
\hline $26-35$ & 57 & 2.70 \\
\hline Sig. & & .756 \\
\hline \multicolumn{3}{|c|}{ Means for groups in homogeneous subsets are displayed. } \\
\hline \multicolumn{3}{|c|}{ a. Uses Harmonic Mean Sample Size = 14.918.} \\
\hline \multicolumn{3}{|c|}{$\begin{array}{l}\text { b. The group sizes are unequal. The harmonic mean } \\
\text { of the group sizes is used. Type I error levels are not } \\
\text { guaranteed. }\end{array}$} \\
\hline
\end{tabular}

Inference: From the above table it is clearly stated that the significant value is 0.955 and it is higher than 0.05 so accept the Null hypothesis. Hence there is no significant relationship between Age group and Redeemption of revenue by retailers.

\section{CONCLUSION}

Purchase level of consumers can be either increased or decreased after this lockdown. Customers one who between the age group of 15 to 25 is involve in greedy purchase or revenge buying due to their age and they are not even think about the family situation, income level etc. During the lock down they collect lot of information through all means of online marketing channel. On the other hand people one who between the age group of 35 and above is involved in low level purchase, even though they are very familiar with the brand, product or service the level of involvement in a purchase can decreased due to the income level, according to their requirement, level of usage and mainly because of their maturedness. Malls and showrooms are locked since lockdown. All the organized and unorganized sector getting adversely affected. Many retailers failed to pay the recent months to mall owners and they are renegotiating the rental contracts. Retailers are facing the major revenue problems so they all depend upon the lifting of lockdown and revenge buying of consumers.

\section{REFERENCE}

B. S. Raman (2002), Consumer Behaviour, Modern Marketing.

IOSR journal of Business and Management e-ISSN: 2278-487x, P-ISSN: 2319-7668, Vol.16, Issue 12, and PP.26-30.

The effect of price bundling on consumer perception of value", journal of service marketing, vol.15, Issue: 4, pp.270-281.

Vasmti Venugopal \&t Rahu V.N. (2006), Consumer Behavior, service of marketing.

https://books.google.co.in>books

https://www.timesnownews.com/business-economy/ economy/article/what-is-revenge-buying/599050 https://www.moneycontrol.com/news/business/ explained-is-coronavirus-lockdown-causing-revengebuying-5315661.html 